\title{
Oncolytic HSV-1 NV1020
}

National Cancer Institute

\section{Source}

National Cancer Institute. Oncolytic HSV-1 NV1020. NCI Thesaurus. Code C2623.

A genetically eng ineered oncolytic virus with potential antineoplastic property. NV1020 is constructed from the herpes simplex virus 1 (HSV-1) by the deletion of a single copy of the gamma (1)34.5 gene and the substitution of the UL23 region of the thymidine kinase (tk) gene with a DNA fragment from HSV-2, thereby resulting in a replication-competent, attenuated virus. This modified virus preferentially transfects rapidly dividing cells, which causes cell lysis in tumor cells. NV1020 has shown reduced virulence against normal tissues and a decreased neurovirulence in comparison with some other modified HSV strains. 